\title{
The Effects of Different Photoactive Dyes on the Adhesion of an Epoxy Resin-based Root Canal Sealer
}

\author{
Farkı Fotoaktif Boyaların Epoksi Rezin Esaslı Kök \\ Kanal Patının Adezyonuna Etkileri
}

\begin{abstract}
Aim: In this study, we aimed to evaluate the effects of four different photoactive dyes on the dentin adhesion of an epoxy resin-based root canal sealer.

Methods: Sixty maxillary central incisors were used. Root canals were prepared up to the size Reciproc \#40, and $2.5 \mathrm{~mL}$ of $5 \% \mathrm{NaOCl}$ was used between each file. The teeth were divided into six groups: Group 1, distilled water (the control group); Group 2, methylene blue; Group 3, toluidine blue; Group 4, indocyanine green; Group 5, Congo red; and Group 6, diode laser. After final irrigation, each canal was irrigated with $2.5 \mathrm{~mL}$ of photoactive dye. Laser irradiation was applied for $1 \mathrm{~min}$ ( $940 \mathrm{~nm}$ wavelength, continuous mode, $1 \mathrm{~W}$ ). The canals were obturated with epoxy resin-based sealer and gutta-percha. Sections measuring $2 \mathrm{~mm}$ in thickness were taken from the apical, middle, and coronal thirds of the roots for the push-out test.

Results: Although the photoactive dyes caused a decrease in the sealer bond strength values, there was no statistically significant difference from the control group or between the dyes. Diode laser irradiation increased bond strength, but there was again no significant difference. Bond strength values decreased from the coronal to the apical region $(5.89 \pm 1.19,3.93 \pm 0.76$, and $3.18 \pm 0.63 \mathrm{MPa}$, respectively).

Conclusion: We observed that the use of photoactive dyes to support root canal disinfection had no negative effect on the bond strength of a resin-based sealer.

Keywords: bond strength; photoactive dye; photodynamic therapy; root canal sealer
\end{abstract}

Öz

Amaç: Bu çalıșmada dört farklı fotoaktif boyanın epoksi rezin esaslı bir kök kanal patının dentin adezyonu üzerindeki etkilerini değerlendirmek amaçlanmıștır.

Yöntem: Altmıș maksiller santral kesici diș kullanıldı. Reciproc \#40 boyutuna kadar kök kanalları șekillendirildi ve her eğe arasında 2,5 mL \%5 NaOCl kullanıldı. Dișler altı gruba ayrıldı: Grup 1, distile su (kontrol grubu); Grup 2, metilen mavisi; Grup 3, toluidin mavisi; Grup 4, indosiyanin yeșili; Grup 5, Kongo kırmızısı; ve Grup 6, diyot lazer. Son irigasyondan sonra her kanal 2,5 mL fotoaktif boya ile yıkandı. Bir dakika boyunca ( $940 \mathrm{~nm}$ dalga boyu, sürekli mod, 1W) lazer ıșını uygulandı. Kanallar epoksi rezin esaslı pat ve gütaperka ile dolduruldu. İtme testi için köklerin apikal, orta ve koronal üçte birlik kısımlarından 2 mm kalınlığında kesitler alındı. Bulgular: Fotoaktif boyalar pat adezyon değerlerinde düșüșe neden olsa da, kontrol grubuna kıyasla ya da boyalar arasında istatistiksel olarak anlamlı bir fark yoktu. Diyot lazer ıșınlaması adezyonu artırdı; ancak yine anlamlı bir fark yoktu. Bağlanma değerleri koronalden apikal

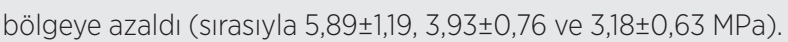

Sonuç: Kök kanal dezenfeksiyonunu desteklemek için fotoaktif boyaların kullanımının rezin esaslı patın adezyonu üzerinde olumsuz bir etkisi olmadığı gözlenmiștir.

Anahtar Sözcükler: bağlanma dayanımı; fotoaktif boya; fotodinamik terapi; kök kanal patı
Ismail Ozkocak', Hakan Gokturk $^{2}$, Irem Cansu Kara ${ }^{3}$

1 Department of Endodontics, Faculty of Dentistry, Antalya Bilim University

2 Department of Endodontics, Faculty of Dentistry, Dokuz Eylül University

${ }^{3}$ Department of Endodontics, Faculty of Dentistry, Bolu Abant İzzet Baysal University

Received/Gelis : 23.10.2020 Accepted/Kabul: 31.05.2021

DOI: 10.21673/anadoluklin.815730

Corresponding author/Yazıșma yazarı İsmail Özkoçak

Antalya Bilim Üniversitesi, Diș Hekimliği Fakültesi, Endodonti Anabilim Dalı, Antalya, Turkey

E-mail:dr_ozkocak@yahoo.com

ORCID

Ismail Ozkocak: 0000-0003-0820-0069 Hakan Gokturk: 0000-0003-3824-2569 Irem Cansu Kara: 0000-0003-0583-8999 


\section{INTRODUCTION}

Endodontic treatment is aimed at the elimination of bacteria from root canal systems, which can be achieved only by a process of antibacterial irrigation and medication, combined with mechanical instrumentation $(1,2)$. Following the cleaning and shaping of the root canal system, successful root canal therapy also requires the use of a filling material to create complete obturation. To achieve this, an ideal root canal sealer must adhere to both the obturation cone and the root dentin (3), preventing leakage and increasing the root's fracture resistance $(2,4)$. However, it has been observed that adhesion and penetration are affected by the smear layer, as well as by the irrigation and pretreatment of dentin (5-8). The epoxy resin-based AH Plus root canal sealer has high physical properties, low resolution, and long-term dimensional stability. AH Plus has been used as a control material in many studies and has been accepted as the gold standard $(9,10)$.

Previous studies have shown that a large number of bacteria remain in the root canal, even with simultaneous cleaning and shaping $(11,12)$. Advanced disinfection strategies are continuously being developed and tested in the field of endodontics. Negative pressure irrigation, sonic and ultrasonic systems, and lasers are only some of the new approaches to root canal disinfection (13).

Photodynamic therapy (PDT) has also been shown to be a promising antimicrobial treatment that can eliminate root canal infections by using a nontoxic photosynthesizing agent followed by pulsed lightsource irradiation $(14,15)$. In PDT, there are two different mechanisms of action: (i) action by electron/ hydrogen transfer directly from the ion-producing photosensitizer or by electron/hydrogen removal through forming free radicals from the substrate molecule-free radicals react with oxygen to generate reactive oxygen species (16); and (ii) action by releasing a type of electronically stimulated, highly reactive oxygen, called singlet oxygen-since such reactions are performed with singlet oxygen products, they are considered the primary pathway for microbial cell destruction (17).

Both mechanisms react with oxygen radicals. The oxide layer, which is released in the bleaching process and consists of oxygen radicals, has been shown to negatively affect the dentin bond strength of resins $(18,19)$. In our literature review, there were few studies $(20,21)$ investigating the effects of PDT on the dentin bond strength of root canal sealers. Thus, in this study we aimed to evaluate the effects of different photoactive dyes on resin dentin bond strength. The null hypothesis tested was that the photosynthesizing agents investigated would have no effect on the epoxy resinbased sealer dentin bond strength.

\section{MATERIALS AND METHODS}

To confirm the presence of a single canal, radiographs of the teeth were taken in the mesiodistal and buccalpalatal directions. Working length was determined with a \#15 K-file. Pathway was created with a \#20 Kfile. For standard root canal preparation width, a \#25$\mathrm{K}$ file was used and smaller K-files were able to reach the root apex. Final diameters were the same. The root canals were prepared in sizes up to Reciproc \#40 (VDW, Munich, Germany), and $2.5 \mathrm{~mL}$ of $5 \%$ sodium hypochlorite $(\mathrm{NaOCl})$ (Wizard, Rehber Chemistry, Istanbul, Turkey) was used between each file (\#25 and \#40 Reciproc files were used for preparation). The final irrigation protocol involved the use of $5 \mathrm{~mL}$ of $5 \%$ $\mathrm{NaOCl}, 5 \mathrm{~mL}$ of $17 \%$ ethylenediaminetetraacetic acid (EDTA) (Imicryl, Konya, Turkey), and $5 \mathrm{~mL}$ of $5 \%$ $\mathrm{NaOCl}$. Before the application of PDT, $10 \mathrm{~mL}$ of distilled water was used, and the root canals were dried with absorbent paper points. The teeth were divided into six groups, with 10 teeth in each: Group 1, distilled water (the control group); Group 2, methylene blue (MB) $(0.1 \mathrm{mg} / \mathrm{mL}$ ) (Sisco Research Lab. Pvt. Ltd., Maharashtra, India); Group 3, toluidine blue (TB) (1 $\mathrm{mg} / \mathrm{mL}$ ) (Sigma-Aldrich Corporation, MO, USA); Group 4, indocyanine green (ICG) (5 mg/mL) (Pulsion Medical Systems SE, Feldkirchen, Germany); Group 5, Congo red (CR) (10 mg/mL) (Sigma-Aldrich Corporation, MO, USA); and Group 6, diode laser (DL) (continuous mode, 1W, $1 \mathrm{~min}$ ) (Epic, Biolase Tech., CA, USA).

After the final irrigation protocol, the roots were irrigated with $2.5 \mathrm{~mL}$ of photoactive dye, which was held in the root canal for $5 \mathrm{~min}$. PDT was then applied with a $200-\mu \mathrm{m}$ diameter tip positioned $2 \mathrm{~mm}$ above the apex, using a 940-nm wavelength laser source 
Table 1. Multiple statistical comparisons of the mean values of bond strength after photodynamic therapy with different dyes

\begin{tabular}{|c|c|c|c|c|}
\hline \multirow{2}{*}{ Groups } & \multicolumn{3}{|c|}{ Mean \pm standard deviation (megapascals) } & \multirow[b]{2}{*}{ Total } \\
\hline & Coronal & Middle & Apical & \\
\hline Control & $6.28 \pm 0.92^{\mathrm{a}, \mathrm{x}}$ & $4.20 \pm 0.79^{\mathrm{b}, \mathrm{x}}$ & $3.18 \pm 0.64^{c, x}$ & $4.55 \pm 1.52^{x}$ \\
\hline MB & $5.83 \pm 1.21^{\mathrm{a}, \mathrm{x}}$ & $3.80 \pm 0.86^{\mathrm{b}, \mathrm{x}}$ & $3.04 \pm 0.71^{\mathrm{b}, \mathrm{x}}$ & $4.22 \pm 1.51^{x}$ \\
\hline TB & $5.59 \pm 1.30^{\mathrm{a}, \mathrm{x}}$ & $3.79 \pm 0.78^{\mathrm{b}, \mathrm{x}}$ & $3.16 \pm 0.50^{\mathrm{b}, \mathrm{x}}$ & $4.18 \pm 1.37^{x}$ \\
\hline ICG & $5.54 \pm 1.24^{\mathrm{a}, \mathrm{x}}$ & $3.76 \pm 0.74^{\mathrm{b}, \mathrm{x}}$ & $3.12 \pm 0.78^{\mathrm{b}, \mathrm{x}}$ & $4.14 \pm 1.39^{x}$ \\
\hline CR & $5.67 \pm 1.41^{\mathrm{a}, \mathrm{x}}$ & $3.75 \pm 0.64^{\mathrm{b}, \mathrm{x}}$ & $3.18 \pm 0.53^{\mathrm{b}, \mathrm{x}}$ & $4.20 \pm 1.42^{\times}$ \\
\hline $\mathrm{DL}$ & $6.45 \pm 0.98^{\mathrm{a}, \mathrm{x}}$ & $4.29 \pm 0.71^{\mathrm{b}, \mathrm{x}}$ & $3.43 \pm 0.65^{b, x}$ & $4.72 \pm 1.50^{x}$ \\
\hline Total & $5.89 \pm 1.19^{\mathrm{a}}$ & $3.93 \pm 0.76^{\mathrm{b}}$ & $3.18 \pm 0.63^{c}$ & \\
\hline
\end{tabular}

CR: Congo red; DL: diode laser; ICG: indocyanine green; MB: methylene blue; TB: toluidine blue

a, b, c: regional significant difference within each disinfection group.

$\mathrm{x}$ : no regional or total difference between the root canal disinfection protocols.

Table 2. Pairwise p-value comparisons of the regions in each group.

\begin{tabular}{|c|c|c|c|c|}
\hline & & Coronal & Middle & Apical \\
\hline \multirow[b]{3}{*}{ Control } & Coronal & - & 0.001 & 0.001 \\
\hline & Middle & 0.001 & - & 0.035 \\
\hline & Apical & 0.001 & 0.035 & - \\
\hline \multirow[b]{3}{*}{ MB } & Coronal & - & 0.001 & 0.001 \\
\hline & Middle & 0.001 & - & 0.18 \\
\hline & Apical & 0.001 & 0.18 & - \\
\hline \multirow[b]{3}{*}{ TB } & Coronal & - & 0.001 & 0.001 \\
\hline & Middle & 0.001 & - & 0.354 \\
\hline & Apical & 0.001 & 0.354 & - \\
\hline \multirow[b]{3}{*}{ ICG } & Coronal & - & 0.001 & 0.001 \\
\hline & Middle & 0.001 & - & 0.346 \\
\hline & Apical & 0.001 & 0.346 & - \\
\hline \multirow[b]{3}{*}{ CR } & Coronal & - & 0.001 & 0.001 \\
\hline & Middle & 0.001 & - & 0.454 \\
\hline & Apical & 0.001 & 0.454 & - \\
\hline \multirow[b]{3}{*}{ DL } & Coronal & - & 0.001 & 0.001 \\
\hline & Middle & 0.001 & - & 0.097 \\
\hline & Apical & 0.001 & 0.097 & - \\
\hline
\end{tabular}

CR: Congo red; DL: diode laser; ICG: indocyanine green; MB: methylene blue; TB: toluidine blue ( $\mathrm{p} \leq 0.05$ was considered statistically significant.)

(Epic, Biolase Tech., CA, USA). The root canal was not irrigated again after irradiation in the DL group.

In the PDT groups the root canals were then rinsed with $10 \mathrm{~mL}$ of distilled water, dried with paper points (Pearl Dent, Ho Chi Minh, Vietnam), and obturated with a paste that contained epoxy resin $\mathrm{AH}$ Plus, Konstanz, Germany) and a \#40/.06 taper guttapercha (Dia Dent, Seoul, Korea) using a single-cone technique. Then the samples were stored for 1 week in a $100 \%$ humid environment at $37^{\circ} \mathrm{C}$. All procedures were carried out by one researcher. The teeth were then embedded in acrylic resin, and 2 mm-thick sections were taken from the apical, middle, and coronal thirds of each root. The samples prepared were placed on a universal test machine (Shimadzu, Kyoto, Japan), and the push-out test was performed (the force lever speed was $1 \mathrm{~mm} / \mathrm{min}$ ) with special tips. The diameter of the tips used covered $90 \%$ of the diameter of the filling material without touching the canal walls. The maximum load required to displace the filling material 
Table 3. Pairwise p-value comparisons of the groups for each region.

\begin{tabular}{|c|c|c|c|c|c|c|c|}
\hline & & Control & MB & TB & ICG & CR & DL \\
\hline \multirow{6}{*}{ Coronal } & Control & - & 1 & 1 & 1 & 1 & 1 \\
\hline & MB & 1 & - & 1 & 1 & 1 & 1 \\
\hline & TB & 1 & 1 & - & 1 & 1 & 0.494 \\
\hline & ICG & 1 & 1 & 1 & - & 1 & 0.369 \\
\hline & CR & 1 & 1 & 1 & 1 & - & 0.795 \\
\hline & DL & 1 & 1 & 0.494 & 0.369 & 0.795 & - \\
\hline \multirow{6}{*}{ Middle } & Control & - & 1 & 1 & 1 & 1 & 1 \\
\hline & MB & 1 & - & 1 & 1 & 1 & 1 \\
\hline & TB & 1 & 1 & - & 1 & 1 & 1 \\
\hline & ICG & 1 & 1 & 1 & - & 1 & 1 \\
\hline & CR & 1 & 1 & 1 & 1 & - & 1 \\
\hline & DL & 1 & 1 & 1 & 1 & 1 & - \\
\hline \multirow{6}{*}{ Apical } & Control & - & 1 & 1 & 1 & 1 & 1 \\
\hline & MB & 1 & - & 1 & 1 & 1 & 1 \\
\hline & TB & 1 & 1 & - & 1 & 1 & 1 \\
\hline & ICG & 1 & 1 & 1 & - & 1 & 1 \\
\hline & CR & 1 & 1 & 1 & 1 & - & 1 \\
\hline & DL & 1 & 1 & 1 & 1 & 1 & - \\
\hline
\end{tabular}

CR: Congo red; DL: diode laser; ICG: indocyanine green; MB: methylene blue; TB: toluidine blue

There was no significant regional difference between the groups ( $\mathrm{p}>0.05$ for each comparison).

was recorded. The load at failure recorded in newtons was divided by the connection surface area to obtain values in megapascals (MPa).

\section{Statistical analysis}

All statistical analyses were performed using the SPSS (v.19) software package (SPSS Statistics 19, SPSS Inc., Somers, NY, USA). Descriptive statistics were presented as mean \pm standard deviation. The sample size calculation was performed using the $\mathrm{G}^{\star}$ Power 3.1 for Windows (Heinrich Heine, Universitat Dessefdorf, Dusseldorf, Germany) software with an alpha error probability of 0.05 , effect size of 0.40 , and power of 0.60 . One-way variance analysis was performed to evaluate the data, and the Bonferroni test was used for multiple comparisons. $\mathrm{p} \leq 0.05$ was considered statistically significant.

\section{Study ethics}

The study protocol was approved by the Clinical Research Ethics Committee of the Bolu Abant İzzet Baysal University (project no. 2019/174).

\section{RESULTS}

The intergroup differences in terms of root canal thirds are summarized in Table 1 and Figure 1. The DL group showed better bond strength results than all other investigated groups in all root canal thirds, but this was not statistically significant ( $\mathrm{p}=1$ for the comparison of the DL and control groups, $\mathrm{p}=0.483$ for $\mathrm{DL}$ and $\mathrm{MB}, \mathrm{p}=0.296$ for DL and TB, $\mathrm{p}=0.185$ for DL and ICG, and $\mathrm{p}=0.366$ for DL and CR). The bond strength values decreased from the coronal to apical region in all groups when compared statistically.

There was no significant difference between the apical and middle regions in terms of bond strength values. However, a significant difference was found between the coronal and middle regions and between the coronal and apical regions in each disinfection group (Table 2).

Although the photoactive dyes caused some decrease in the bond strength values of resin-containing paste when compared to the control group, there was no significant difference. Also, there was no significant difference between the dye groups in all thirds (Table 3). 


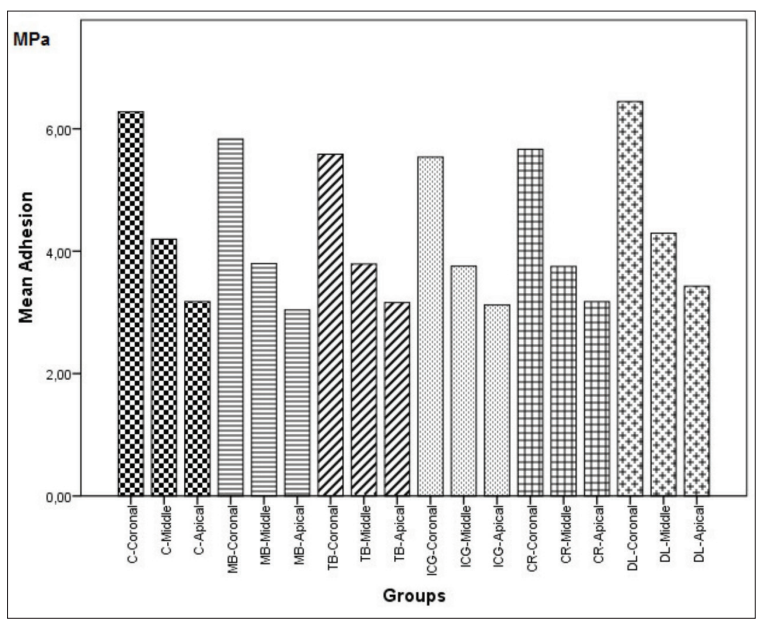

Figure 1. Graphical view of the results

\section{DISCUSSION AND CONCLUSION}

The antibacterial efficacy of PDT has been evaluated and demonstrated in many studies (22-24), but still little is known about its impact on the adhesion properties of root canal sealers. PDT works by producing oxygen radicals. Agents used in bleaching create a whitening effect using oxygen compounds, and the oxide layer that is formed in this process disrupts the bonding of resins. It is necessary that either clinicians wait before restoration or the oxide layer be eliminated using antioxidants $(18,19,40-42)$. In the present study, the effects of PDT on the dentin bond strength of a resin-based root canal sealer was evaluated; however, it was possible to compare different photoactive dyes. According to our results, there was no significant difference between the investigated disinfection protocols and the control group in terms of sealer bond strength. Therefore, the null hypothesis was accepted.

In our study, the bond strength values decreased from the coronal to the apical region, with significant difference between the coronal and middle regions and between the coronal and apical regions. Neelakantan et al. reported that AH Plus was chemically bound to dentin collagen, although bond strength was affected by certain irrigation solutions. The researchers also showed a decrease in bond strength values from the coronal to the apical region (25).

Ramos et al. evaluated the effect of PDT on the dentin adhesion of fiber posts bonded with resin-based cements. They reported that PDT decreased bond strength values in the coronal region while showing similar values in the apical and middle thirds. Our results are similar to those found in that study, which used laser devices with 780-808-nm wavelengths and a $0.005 \%$ methylene blue dye (26). We concluded that the decrease in our study was due to the difficulty of removing the smear layer in the apical region, the decreasing number of dentine tubules toward the apical region, and the connection surface area being smaller in the apical region.

Menezes et al. evaluated the effects of PDT and nonthermal plasma on the dentin bond strength and penetration of AH Plus and MTA Fillapex, and reported that bond strength values for AH Plus in the nonthermal plasma group were the same as in the control group whereas AH Plus bond strength decreased in the PDT group. It was shown that both applications resulted in a decrease in dentine tubule penetration (6). Although bond strength values decreased with PDT in our study, we found no statistically significant difference from the control group. This may be due to study design differences, such as different laser parameters. We used a single-cone technique while Tagger's hybrid thermomechanical compaction technique was used in the cited study. In another study, it had been reported that Tagger's hybrid technique involved minimal sealer use and increased the guttapercha area in the coronal and middle thirds (27).

Menezes et al. used a 660-nm wavelength laser for 90 seconds. The absorption values of the photoactive dyes used during PDT vary according to the wavelengths used, and the manufacturer gives these absorption values in the manual provided. For example, the highest absorption value for ICG is an $810-\mathrm{nm}$ wavelength (28); for TB, a 633-nm wavelength; and for $\mathrm{MB}$, a $664 \mathrm{~nm}$ wavelength, as has been reported in previous studies (29). However, in the literature there is still no consensus on which photosensitizer, irradiation period, power or wavelength is the best for PDT. Although mostly low-wavelength light sources are used in PDT, Nagai et al. detected similar antibacterial activity on dentin plates infected with Streptococcus mutans in 650-nm-wavelength-laser-MB and 940-nm-wavelength-laser-MB groups. A high bactericidal effect was observed in the 940 -nm-wavelength- 
laser-MB group, although the wavelength of the laser does not match the excitation wavelength for $\mathrm{MB}(30)$.

Ok et al. studied the effect of photoactive disinfection on bond strength in root canals obturated with $\mathrm{AH}$ Plus and gutta-percha. For PDT, the researchers used a $0.01 \%$ TB dye (with a 2-min hold) and an LED light source with a wavelength of $625-635 \mathrm{~nm}$ for 20 seconds. They reported that PDT had no effect on the dentin bond strength of root canal sealers (31). Although the light source and parameters used were different, the present study results are similar to those findings.

The antimicrobial effectiveness of a 940 -nm wavelength laser and its effectiveness in PDT when used with photoactive dyes have been demonstrated in several previous studies (32-35). It appears that no other study has provided a comparison of different dyes, and therefore the present study is valuable for examining the effects of four different photosensitizers on the bond strength of an epoxy resin-based root canal sealer.

We found that DL application caused an increase in the bond strength values, although there was no significant difference from the other groups, and concluded that this increase was due to the modification of dentin (36), a temperature increase on the root canal surface (37), evaporation of the final irrigation solution in the dentinal tubules (38), and the hydrophobic structure of the AH Plus root canal sealer (39).

Many researchers have reported that applications of bleaching negatively affect the bond strength of resins in bonding to enamel and dentin, due to the release of oxygen that prevents resin polymerization at the interface. The solution to this is to wait 1 to 2 weeks between the bleaching application and final restoration $(40,41)$. Research has also shown that prolonged periods of bleaching lead to greater decreases in bond strength (42).

Our findings showed that, although PDT caused some decrease in the resin bond strength, there was no statistically significant difference from the control group and between the laser groups. The inconsistency between findings of the present study and previous research can be linked to the fact that oxygen concentration in PDT may be less, that the oxygen radicals produced may be different (i.e., singlet oxygen), that the application time is less in PDT, and that the laser beam may cause morphological changes on the surface of the dentin. In our study, PDT was applied using a dye which was kept in the canal for $5 \mathrm{~min}$, before a 1-min laser irradiation was carried out.

Finally, the main limitations of our study are the in vitro design, the use of only a single sealer, and the use of a new DL only at a single wavelength. Future studies should examine the effects of PDT with different laser wavelengths and irradiation periods and consider the adhesion properties of sealers that include different materials. In conclusion, we found that PDT with four different photoactive dyes and a $940 \mathrm{~nm}$-wavelength laser was a safe method for root canal disinfection, with PDT having no negative effect on the dentin bond strength of resin-based sealers.

\section{Conflict-of-Interest and Financial Disclosure}

The authors declare that they have no conflict of interest to disclose. The authors also declare that they did not receive any financial support for the study.

\section{REFERENCES}

1. Peters OA, Schonenberger K, Laib A. Effects of four $\mathrm{Ni}$-Ti preparation techniques on root canal geometry assessed by microcomputed tomography. Int Endod J. 2001;34(3):221-30

2. Ghoneim AG, Lutfy RA, Sabet NE, Fayyad DM. Resistance to fracture of roots obturated with novel canal-filling systems. J Endod. 2011;37(11):1590-2.

3. Branstetter J, von Fraunhofer JA. The physical properties and sealing action of endodontic sealer cements: a review of the literature. J Endod. 1982;8(7):312-6.

4. Osiri S, Banomyong D, Sattabanasuk V, Yanpiset K. Root reinforcement after obturation with calcium silicate-based sealer and modified gutta-percha cone. J Endod. 2018;44(12):1843-8.

5. Keine KC, Kuga MC, Tormin FBC, Venção AC, Duarte MAH, Chávez-Andrade GM, et al. Effect of peracetic acid used as single irrigant on the smear layer, adhesion, and penetrability of AH Plus. Braz Oral Res. 2019;33:e057.

6. Menezes M, Prado M, Gomes B, Gusman H, Simão R. Effect of photodynamic therapy and non-thermal plasma on root canal filling: analysis of adhesion and sealer penetration. J Appl Oral Sci. 2017;25(4):396-403. 
7. Gonçalves L, Silva-Sousa YTC, Neto WR, Teixeira CS, Sousa-Neto MD, Alfredo E. Effect of different irrigation protocols on the radicular dentin interface and bond strength with a metacrylate-based endodontic sealer. Microsc Res Tech. 2014;77(6):446-52.

8. Ayrancı LB, Köseoğlu M. The evaluation of the effects of different irrigating solutions and laser systems on adhesion of resin-based root canal sealers. Photomed Laser Surg. 2014;32(3):152-9.

9. Flores DS, Rached FJ Jr, Versiani MA, Guedes DF, Sousa-Neto MD, Pécora JD. Evaluation of physicochemical properties of four root canal sealers. Int Endod J. 2011;44(2):126-35.

10. Torres FFE, Zordan-Bronzel CL, Guerreiro-Tanomaru JM, Chávez-Andrade GM, Pinto JC, Tanomaru-Filho M. Effect of immersion in distilled water or phosphatebuffered saline on the solubility, volumetric change and presence of voids within new calcium silicate-based root canal sealers. Int Endod J. 2020;53(3):385-91.

11. Lin J, Shen Y, Haapasalo M. A comparative study of biofilm removal with hand, rotary nickel-titanium, and self-adjusting file instrumentation using a novel in vitro biofilm model. J Endod. 2013;39(5):658-63.

12. Navabi AA, Khademi AA, Khabiri M, Zarean P, Zarean P. Comparative evaluation of Enterococcus faecalis counts in different tapers of rotary system and irrigation fluids: an ex vivo study. Dent Res J. 2018;15(3):173-9.

13. Plotino G, Cortese T, Grande NM, Leonardi DP, Di Giorgio G, Testarelli L, et al. New technologies to improve root canal disinfection. Braz Dent J. 2016;27(1):38.

14. Gursoy H, Ozcakir-Tomruk C, Tanalp J, Yilmaz S. Photodynamic therapy in dentistry: a literature review. Clin Oral Investig. 2013;17(4):1113-25.

15. Chrepa V, Kotsakis GA, Pagonis TC, Hargreaves KM. The effect of photodynamic therapy in root canal disinfection: a systematic review. J Endod. 2014;40(7):891-8.

16. Foote CS. Definition of type I and type II photosensitized oxidation. Photochem Photobiol. 1991;54(5):659.

17. Konopka K, Goslinski T. Photodynamic therapy in dentistry. J Dent Res. 2007;86(8):694-707.

18. Karadas M, Demirbuga S. Influence of a short-time antioxidant application on the dentin bond strength after intracoronal bleaching. Microsc Res Tech. 2019;82(10):1720-7.

19. Harrison MS, Wang Y, Frick KJ, Moniz J, Walker MP. Effects of alpha-tocopherol antioxidant on dentin-composite microtensile bond strength after sodium perborate bleaching. J Endod. 2019;45(8):1053-9.
20. Yavari H, Ghasemi N, Divband B, Rezaei Y, Jabbari G, Payahoo S. The effect of photodynamic therapy and polymer solution containing nano-particles of $\mathrm{Ag} / \mathrm{ZnO}$ on push-out bond strength of the sealers AH-Plus and MTA Fillapex. J Clin Exp Dent. 2017;9(9):e1109-14.

21. Banci HA, Strazzi-Sahyon HB, Duarte M, Cintra L, Gomes-Filho JE, Chalub LO, et al. Influence of photodynamic therapy on bond strength and adhesive interface morphology of MTA based root canal sealer to different thirds of intraradicular dentin. Photodiagnosis Photodyn Ther. 2020;32:102031.

22. Camacho-Alonso F, Julián-Belmonte E, Chiva-García F, Martínez-Beneyto Y. Bactericidal efficacy of photodynamic therapy and chitosan in root canals experimentally infected with Enterococcus faecalis: an in vitro study. Photomed Laser Surg. 2017;35(4):184-9.

23. Katalinić I, Budimir A, Bošnjak Z, Jakovljević S, Anić I. The photo-activated and photo-thermal effect of the $445 / 970 \mathrm{~nm}$ diode laser on the mixed biofilm inside root canals of human teeth in vitro: a pilot study. Photodiagnosis Photodyn Ther. 2019;26:277-83.

24. Zorita-García M, Alonso-Ezpeleta LÓ, Cobo M, Del Campo R, Rico-Romano C, Mena-Álvarez J, et al. Photodynamic therapy in endodontic root canal treatment significantly increases bacterial clearance, preventing apical periodontitis. Quintessence Int. 2019;50(10):7829.

25. Neelakantan P, Sharma S, Shemesh H, Wesselink PR. Influence of irrigation sequence on the adhesion of root canal sealers to dentin: a Fourier transform infrared spectroscopy and push-out bond strength analysis. J Endod. 2015;41(7):1108-11.

26. Ramos ATPR, Belizário LG, Venção AC, Jordão-Basso KCF, Rastelli ANS, Andrade MF, et al. Effects of photodynamic therapy on the adhesive interface of fiber posts cementation protocols. J Endod. 2018;44(1):173-8.

27. Marciano MA, Bramante CM, Duarte MA, Delgado RJ, Ordinola-Zapata R, Garcia RB. Evaluation of single root canals filled using the lateral compaction, Tagger's hybrid, microseal and guttaflow techniques. Braz Dent J. 2010;21(5):411-5.

28. Fickweiler S, Szeimies RM, Bäumler W, Steinbach P, Karrer S, Goetz AE, et al. Indocyanine green: intracellular uptake and phototherapeutic effects in vitro. J Photochem Photobiol B. 1997;38(2-3):178-83.

29. Saha B, Chowdhury S, Sanyal D, Chattopadhyay K, Kumar GS. Comparative study of toluidine blue O and methylene blue binding to lysozyme and their inhibitory effects on protein aggregation. ACS Omega. 
2018;3(3):2588-601.

30. Nagai Y, Suzuki A, Katsuragi H, Shinkai K. Effect of antimicrobial photodynamic therapy (aPDT) on the sterilization of infected dentin in vitro. Odontology. 2018;106(2):154-61.

31. Ok E, Ertas H, Saygili G, Gok T. Effect of photoactivated disinfection on bond strength of root canal filling. J Endod. 2013;39(11):1428-30.

32. Tilakchand M, Singh NN, Yeli MM, Naik BD. Evaluation of the antibacterial efficacy of EZLASE diode LASER on the infected root canal system: an in vivo study. J Conserv Dent. 2018;21(3):306-10.

33. Namvar MA, Vahedi M, Abdolsamadi HR, Mirzaei A, Mohammadi Y, Jalilian FA. Effect of photodynamic therapy by 810 and $940 \mathrm{~nm}$ diode laser on herpes simplex virus 1: an in vitro study. Photodiagnosis Photodyn Ther. 2019;25:87-91.

34. Aytac Bal F, Ozkocak I, Cadirci BH, Karaarslan ES, Cakdinleyen M, Agaccioglu M. Effects of photodynamic therapy with indocyanine green on Streptococcus mutans biofilm. Photodiagnosis Photodyn Ther. 2019;26:229-34.

35. Sen OG, Kaya M. Effect of root canal disinfection with a diode laser on postoperative pain after endodontic retreatment. Photobiomodul Photomed Laser Surg. 2019;37(2):85-90.

36. Osmari D, Ferreira ACO, Bello MC, Susin AH, Aranha ACC, Marquezan M, et al. Micromorphological evaluation of dentin treated with different desensitizing agents. J Lasers Med Sci. 2013;4(3):140-6.
37. Yilmaz Y, Keles S, Mete A. Temperature changes in the pulpal chamber and the sealing performance of various methods of direct pulp capping of primary teeth. Eur J Paediatr Dent. 2013;14(2):95-100.

38. Kasraei S, Yarmohamadi E, Jahromi PR, Akbarzadeh M. Effect of 940nm diode laser irradiation on microtensile bond strength of an etch and rinse adhesive (Single Bond 2) to dentin. J Dent. 2019;20(1):30-6.

39. Pantoja CAMS, Silva DHD, Soares AJ, Ferraz CCR, Gomes BPFA, Zaia AA, et al. Influence of ethanol on dentin roughness, surface free energy, and interaction between $\mathrm{AH}$ Plus and root dentin. Braz Oral Res. 2018;32:e33

40. Swift EJ Jr. Critical appraisal. Reversal of compromised bonding after bleaching. J Esthet Restor Dent. 2012;24(5):357-61.

41. Titley KC, Torneck CD, Ruse ND, Krmec D. Adhesion of a resin composite to bleached and unbleached human enamel. J Endod. 1993;19(3):112-5.

42. Santos GC, Baia JC, Ribeiro ME, Lima RR, Sousa Júnior MHSE, Loretto SC. Influence of prolonged bleaching with $4 \%$ hydrogen peroxide containing calcium and different storage times on the bond strength to enamel. J Contemp Dent Pract. 2019;20(2):216-20. 